\title{
Review
}

\section{Neurological Disorders and Risk of Arrhythmia}

\author{
Joyce Bernardi, Kelly A. Aromolaran and Ademuyiwa S. Aromolaran *(D)
}

check for

updates

Citation: Bernardi, J.; Aromolaran, K.A.; Aromolaran, A.S. Neurological Disorders and Risk of Arrhythmia. Int. J. Mol. Sci. 2021, 22, 188. https://dx.doi.org/10.3390/ ijms22010188

Received: 1 December 2020

Accepted: 24 December 2020

Published: 27 December 2020

Publisher's Note: MDPI stays neutral with regard to jurisdictional claims in published maps and institutional affiliations.

Copyright: () 2020 by the authors. Licensee MDPI, Basel, Switzerland. This article is an open access article distributed under the terms and conditions of the Creative Commons Attribution (CC BY) license (https: / creativecommons.org/ licenses/by/4.0/).
Biomedical Research and Translational Medicine, Masonic Medical Research Institute, 2150 Bleecker St., Utica, NY 13501, USA; jbernardi@mmri.edu (J.B.); kellyaromolaran@gmail.com (K.A.A.)

* Correspondence: aaromolaran@mmri.edu

\begin{abstract}
Neurological disorders including depression, anxiety, post-traumatic stress disorder (PTSD), schizophrenia, autism and epilepsy are associated with an increased incidence of cardiovascular disorders and susceptibility to heart failure. The underlying molecular mechanisms that link neurological disorders and adverse cardiac function are poorly understood. Further, a lack of progress is likely due to a paucity of studies that investigate the relationship between neurological disorders and cardiac electrical activity in health and disease. Therefore, there is an important need to understand the spatiotemporal behavior of neurocardiac mechanisms. This can be advanced through the identification and validation of neurological and cardiac signaling pathways that may be adversely regulated. In this review we highlight how dysfunction of the hypothalamic-pituitary-adrenal (HPA) axis, autonomic nervous system (ANS) activity and inflammation, predispose to psychiatric disorders and cardiac dysfunction. Moreover, antipsychotic and antidepressant medications increase the risk for adverse cardiac events, mostly through the block of the human ether-a-go-go-related gene (hERG), which plays a critical role in cardiac repolarization. Therefore, understanding how neurological disorders lead to adverse cardiac ion channel remodeling is likely to have significant implications for the development of effective therapeutic interventions and helps improve the rational development of targeted therapeutics with significant clinical implications.
\end{abstract}

Keywords: mental illness; cardiovascular disease; ion channels; antipsychotic drugs

\section{Introduction}

Psychiatric disorders are widely prevalent globally, affecting about $25-30 \%$ of patients in Europe and the United States, with anxiety disorder and depression being the most common conditions (7\% and 5\% respectively) [1]. Cardiovascular disorders (CVDs) are the leading cause of death in the general population, but also among patients with neurological diseases [2], suggesting a link between these two populations.

In general, a complex set of behavioral and psychosocial aspects are mediators for increased CVD risk, including smoking, alcohol and substance abuse, poor diet and reduced physical activity that can lead to obesity, non-adherence to medications and sleep disorders, anger and hostility, social isolation and low socioeconomic status [3-5]. These CVD risk factors are significantly present among subjects with mental illness, resulting in an additive effect over the disease-related biological risk factors [6] that these patients have for CVD. Notably, drug therapies for the treatment of mental disorders predispose to a variety of physical illnesses (obesity, diabetes, thyroid disorders, gastrointestinal, respiratory and renal diseases, etc.), including CVD and arrhythmias [7,8]. All-cause mortality in general, and cardiac mortality in particular, is higher in antipsychotic users compared to nonusers [9].

Therefore, there is an urgent need for management strategies to reduce the CVD risk in this population group. A holistic understanding of the molecular mechanisms that underlie biological stressors is important in defining psychological and physical outcomes that determine vulnerability to disease conditions, and in particular CVD [10]. This is also valid for CVD patients, in which psychological and psychiatric problems (such as 
depression and anxiety) that may arise following major cardiac events are often underreported and undertreated. Therefore, a prompt identification and treatment of potential psychological conditions could help reduce the risk of further cardiac events and improve the outcome in cardiac patients.

In this review we discuss existing knowledge of the intimate and delicate interaction between neurological disorders and CVD, taking into consideration common and distinct pathological mechanisms. In particular, we discuss the potential involvement of pathological ion channel modulation in the etiology of neurological disorders with significant implications for CVD and ultimately arrhythmias. Our hope is that this review will be of great interest to a wide range of the scientific community and more specifically neurology and cardiology research investigators. In this context our goal is to further highlight unacknowledged common and unique molecular mechanisms of neurological channelopathies and cardiomyopathies that merits significant investigation.

\section{Psychiatric Disorders and Cardiovascular Diseases}

A bidirectional relationship between mental illness and CVD is known to exist. Among mental illnesses, depression, post-traumatic stress disorder (PTSD), anxiety, schizophrenia and autism are the most commonly studied due to their crucial predisposition to adverse cardiac events [2,11-15]. For example, depression is a mood disorder that varies from mild to major depressive symptoms and is characterized by sadness, pervasive low mood and loss of interest (anhedonia) lasting for 2 weeks or more [2,11]. Depression and cardiovascular disorders are closely related. CVD can cause depressive symptoms, and the prevalence of depression in patients with CVD is 3 times higher than in the general population [16]. Furthermore, depression has been reported to be an independent risk factor for cardiac events [17], increasing the incidence of CVD in previously healthy people [18].

Depression and anxiety are interlinked pathologies, but the associated mechanisms are unknown or poorly understood. Notably, patients with high levels of anxiety have an increased risk for sudden cardiac death (SCD) $[13,19,20]$. Indeed, hyperventilation, that may occur during an acute panic/anxiety attack, can induce coronary artery spasm [21], which in turn may eventually lead to myocardial ischemia and fatal ventricular arrhythmias [22,23].

Depressive and anxiety disorders have a high comorbidity and share symptoms with PTSD, a disease state defined by trauma and stressor-related diseases that may develop after a major traumatic event (including combat, sexual assault, etc.). Further, intrusive thoughts, negative cognitions and mood, avoidance and hyperarousal are associated with PTSD and this, in turn, leads to severe distress. For example, clinically relevant studies in the Veterans population have highlighted the association between PTSD and CVD, with PTSD patients having double the risk of developing adverse cardiac events [24-28]. Moreover, experiencing a life-threating illness, including a major cardiac event, can elicit PTSD, and the persistence of PTSD symptoms can increase the likelihood of developing recurrent CVD [29-31].

Schizophrenia is another psychiatric disorder significantly associated with augmented risk for CVD [14,32]. Schizophrenia is defined by the presence of two or more characteristic symptoms, including hallucinations, disorganized speech and delusions. Patients with schizophrenia are likely to have a 10 years lower life-expectancy compared to the general population, and this dramatic reduction is underscored by a high incidence of suicide and an elevated CVD risk [33].

Autism spectrum disorder (ASD) is a neurodevelopmental disorder that is characterized by restricted interests, repetitive behaviors and difficulties in communication and social interaction. ASD is commonly comorbid with other psychiatric disorders (depression and anxiety), and also with epilepsy, suggesting the existence of shared biological mechanisms between these conditions. Congenital heart diseases (CHDs) such as atrial and ventricular septal defects have been associated with an increased risk of developing ASD [34] and epilepsy [35]. While the exact cause is unknown, studies have suggested that there could be common genetic links [36], environmental causes or it could be due to 
surgeries or other clinical outcomes due to CHD. For example, increased seizures for CHD patients, in general and particularly after surgery, lead to deficits in neural development that might be due to cerebral hypoperfusion $[37,38]$, and further reinforces an important physiological interplay between these disease pathologies. Furthermore, ASD patients are more likely to have hyperlipidemia, which is a known risk factor for diabetes, obesity and CVD [15]. Others and we have demonstrated that pathological levels of the saturated free fatty acid, palmitic acid, led to adverse remodeling of major cardiac ion channels in distinct animal models [39-42]. These findings suggest a higher likelihood of experiencing a fatal arrhythmia event and ultimately the transition to heart failure and sudden cardiac death in ASD patients with confounding hypercholesterolemia and/or hypertriglyceridemia. Future studies of the mechanisms of the neurological-cardiac axis that include patients with lipid metabolism disorders are likely to provide novel and additional insights that will improve knowledge of vulnerability of ASD patients to metabolic disorders and ultimately cardiac dysfunction.

Antipsychotic and antiepileptic medications have been reported to have a range of cardiac side-effects, including orthostatic hypotension [43], cardiomyopathy [44], QT prolongation [45] and increased risk for SCD [9]. Moreover, antidepressant drugs have been associated with adverse cardiac effects: the selective serotonin reuptake inhibitors (SSRIs) and particularly the tricyclic antidepressants are known to cause prolongation of the heart rate corrected $\mathrm{QT}$ interval $\left(\mathrm{QT}_{\mathrm{c}}\right)$ on an ECG and predispose to ventricular arrhythmias $[46,47]$. These cardiotoxic effects of psychiatric disorder therapeutics are of particular importance in patients with an underlying CVD.

Neurological conditions, including subarachnoid hemorrhage, can also be associated with cardiac dysfunction. In this context the Krzych lab demonstrated that the neurocardiogenic injury that follows a subarachnoid hemorrhage is characterized by ST-segment elevation and $\mathrm{QT}_{\mathrm{c}}$ prolongation on the ECG, moderate elevation in Troponin C levels and myocardial necrosis [48]. These clinical presentations are reminiscent of Takotsubo cardiomyopathy a cardiac condition that develops in response to severe psychological distress, or an intense emotional or stressful experience [49]. A catecholamine-induced toxicity in cardiomyocytes has been identified as a common pathological mechanism between the two conditions, and further highlights a critical link and/or interplay between cellular functions of the brain and heart.

\section{Common Molecular Mechanisms of Cardiovascular Disorders Acquired in Mental Disorders}

Psychiatric diseases share common biological, behavioral and psychosocial risk factors that increase the likelihood of developing CVD [50]. Dysfunction of the hypothalamicpituitary-adrenal (HPA) axis and autonomic nervous system (ANS) activity, inflammation and oxidative stress are key cellular mechanisms that play an important role in the development of mental conditions [51], as summarized in Figure 1.

The HPA axis is responsible for the release of different neuropeptides and hormones, including cortisol, crucial for the physiological response to stress and the subsequent regulation of individual or multiple combinations of homeostatic processes that includes emotional, metabolic, cardiovascular and immune mechanisms. Prolonged, excessive or insufficient activity of the HPA axis, particularly in conjunction with repetitive exposure to stress, may result in the development of psychiatric disorders, such as depression, anxiety disorders, PTSD, schizophrenia and autism $[52,53]$. Similarly, HPA axis hyperactivity has been associated with increased CVD risk and mortality $[54,55]$. 


BEHAVIORAL \& PSYCHOSOCIAL FACTORS
\begin{tabular}{|ll|}
\hline Smoking & Medication Non-Adherence \\
High Fat Diet & Low Socioeconomic Status \\
Alcohol/Drug Abuse & Social Isolation \\
Low Exercise & Poor Sleep \\
\hline
\end{tabular}

\section{BIOLOGICAL FACTORS}

\begin{tabular}{|c|c|}
\hline $\begin{array}{l}\text { HPA axis alteration } \\
\uparrow \downarrow \text { Cortisol } \\
\text { ANS dysfunction } \\
\uparrow \mathrm{SNS}(\uparrow \mathrm{HR}, \mathrm{BP}, \mathrm{NE}) \\
\downarrow \mathrm{PNS}\end{array}$ & $\begin{array}{l}\quad \underline{\text { Inflammation }} \\
\uparrow \text { IL-1- } \beta, \text { IL- } 6, \text { TNF- } \alpha \\
\downarrow \text { IL-4, IL-10 }\end{array}$ \\
\hline $\begin{array}{r}\text { Cardiac Ion Chanr } \\
\left(\mathrm{I}_{\mathrm{K}}, \mathrm{I}_{\mathrm{Ks}}, \mathrm{I}_{\mathrm{Ca}, \mathrm{I}}\right.\end{array}$ & ysfunction \\
\hline
\end{tabular}

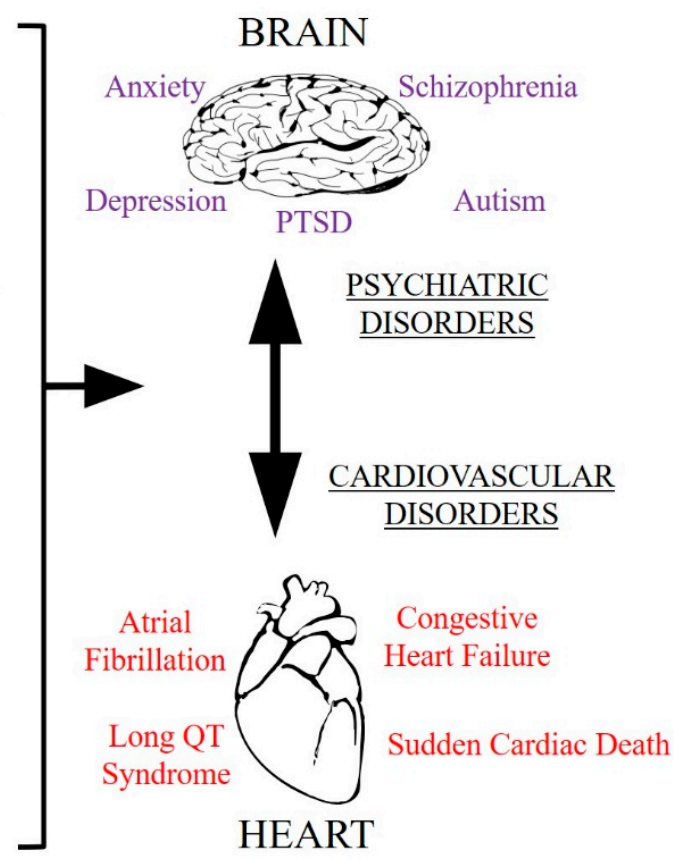

Figure 1. Functional interaction between brain and heart disorders. Scheme of the behavioral, psychosocial and biological risk factors shared among psychiatric disorders that are involved in the increased incidence of cardiovascular diseases. HPA axis = Hypothalamic-Pituitary-Adrenal axis, ANS = Autonomic Nervous System, SNS = Sympathetic Nervous System, PNS = Parasympathetic Nervous System, HR = Heart Rate, BP = Blood Pressure, NE = Norepinephrine, TNF- $\alpha=$ Tumor Necrosis Factor Alpha, PTSD = Post-Traumatic Stress Disorder, $I_{K r}=$ Rapid Delayed Rectifier Potassium Current, $I_{K s}=$ Slow Delayed Rectifier Potassium Current, $I_{C a, L}=$ L-Type Calcium Current, $I_{N a}=$ Sodium Current, $\uparrow$ increased, $\downarrow$ decreased.

The stress response system is defined by both the HPA axis, and the ANS. The ANS is composed of two branches: the sympathetic nervous system (SNS) and the parasympathetic nervous system (PNS). In response to stressful situations, the SNS is the dominant mechanism exemplified by the activation of the fight-or-flight response, which leads to catecholamine (noradrenaline and norepinephrine) release. Furthermore, ANS activation leads to physiological changes, which include an increase in heart rate (HR) and blood pressure. SNS hyperactivation coupled with blunted PNS activity can play a role in different psychiatric disorders [56,57]. The resulting ANS dysfunction is characterized by high levels of circulating catecholamines (primarily norepinephrine), higher $\mathrm{HR}$ at rest, low $\mathrm{HR}$ variability $(\mathrm{HRV})$, baroreflex dysfunction and increased $\mathrm{QT}_{\mathrm{c}}$ variability $[56,58-60]$. The relative functional contributions of the different altered neurological signaling mechanisms to cardiac dysfunction are unknown. Therefore, studies that provide molecular mechanisms of common or unique signaling pathways are likely to provide mechanistic insights that will improve our understanding of the delicate link between neurological disorders and vulnerability to arrhythmogenesis and heart failure.

There is evidence that a dysregulated stress response system that occurs in mental disorders, leads to hyperinflammation, which is an independent risk factor for CVD [61]. Furthermore "sterile inflammation", a process that is not due to a pathogen, but can result after chronic stress, is evident in different mental disorders. As a consequence of altered neurohumoral function, the pathological levels of proinflammatory cytokines including interleukin (IL)-6, IL-1 $\beta$ and tumor necrosis factor alpha (TNF- $\alpha$ ) can be triggered, especially in microglia and astrocytes. In fact, an increased proinflammatory setting is reported in patients with depression, schizophrenia, PTSD, anxiety disorder and ASD [62-66]. Inflammation is a shared mechanism between psychiatric disorders and CVD. Proinflammatory cytokines like IL-6, IL-1 $\beta$ and TNF $\alpha$ are involved in the progression of chronic heart failure through remodeling and increased fibrosis [67], and these alterations can further lead to susceptibility of ventricular tissue to arrhythmias. Additionally, cytokines have been shown 
to modulate different cardiac ion channels and this interaction can have important effects on action potential (AP) and QT duration [68], having either protective or pathological consequences, such as promotion of arrhythmias [69]. IL-1 $\beta$ and IL-6 increase the L-type calcium current $\left(I_{\mathrm{CaL}}\right)$, while TNF- $\alpha$ decreases both the transient outward $\left(I_{\mathrm{to}}\right)$ and the rapid delayed rectifier $\left(I_{\mathrm{Kr}}\right)$ potassium currents, all leading to an increase of AP duration (APD) in cardiomyocytes [70-73]. IL-1 and TNF- $\alpha$ have been positively associated with $\mathrm{QT}_{\mathrm{c}}$ prolongation [74,75], while IL-6 and IL-8 have been correlated with SCD [76,77]. There is also a crosstalk between inflammation and ANS: stimulation of the SNS has been shown to increase the level of proinflammatory cytokines, while PNS activation seems to promote the reduction of such cytokines; at the same time these pro-inflammatory cytokines modulate ANS action on the heart, mainly acting on HRV [69].

Comprehensive behavioral animal studies, in response to specific (acute vs. chronic) stressors have revealed subjective outcomes, defined by distinctive active and/or passive coping mechanism. For example, an active coping mechanism would result in a fight-orflight response, while a passive coping response is characterized by immobility, avoidance and withdrawal. The prevalence of one approach over the other can then influence the psychological and metabolic state of the organism. Indeed, stress-susceptible animals usually display altered HPA axis function, increased sympathetic activity and reduced parasympathetic tone, with associated pathological elevations of catecholamines, high blood pressure, increased resting HR, decreased HRV [78] and a higher secretion of proinflammatory cytokines. This finding would suggest that stress-resistant animals are likely to display an opposing phenotype that includes a normal representation of anti-inflammatory cytokines, including IL-4 and IL-10 [79-81]. Moreover, social defeat and isolation have been shown to have cardiac consequences (decreased HRV and hypertrophy) in animal experiments, and aggressive animals were more vulnerable to heart disease [78], suggesting that coping mechanisms are related with risk for CVD.

\section{Evidence for a Potential Role for Ion Channels Linking Neuropsychiatric Disorders and CVD}

Ion channels are widely distributed in the brain and heart. Both neurons and cardiomyocytes are excitable cells; therefore, the biophysical properties and regulation of ion channels are important for their functional activity. In some cases, a connection between cardiac and neuronal ion channel dysfunction can be present, resulting in clinical conditions with both psychiatric and cardiac phenotypes. This is highlighted in Timothy syndrome (TS) or long QT syndrome type 8 (LQT8).

TS is a multisystemic syndrome that is caused by congenital or inherited mutations in the CACNA1C gene, which encodes for the alpha $1 \mathrm{C}$ subunit of the L-type calcium channel (Cav1.2) and contributes prominently to normal cardiac repolarization and neurological functions including synaptic plasticity and long-term potentiation. TS is characterized by a combination of QTc prolongation, syndactyly and autism. Typical TS (type 1) results from a recurrent de novo mutation, G406R in CACNA1C exon 8A, while atypical TS (type 2) characterized by the lack of syndactyly phenotype, is caused by G406R and G402S mutations in the alternatively spliced exon 8 . A de novo CACNA1C mutation, the G402S substitution in exon 8 , is associated exclusively with a cardiac specific phenotype (including LQTS and cardiac arrest), with no signs of multiorgan disease manifestations of classical TS [82]. Conversely, the A1473G mutation can induce additional central and peripheral neurological symptoms (stroke, seizure, cortical blindness and development delay) in LQT8 patients [83], and of particular note, a novel A1024G mutation has been reported in patients with extracardiac symptoms but no QT prolongation [84]. The phenotypical variability of this disease has been attributed to the fact that distinct missense mutations may differently affect excitable and non-excitable cells [85].

Mutations in the KCNJ2 gene, that encodes for the Kir2.1 channel subunit also led to channelopathies defined by defects in both cardiac and neuronal mechanisms. Kir2.1 generates the inward-rectifier $\mathrm{K}$ current $I_{\mathrm{K} 1}$, which is abundant in the brain and human cardiac and skeletal muscles [86]. KCNJ2 mutations (including T192A and R67W) that lead 
to a loss-of-function phenotype have been associated with Andersen-Tawil syndrome (or LQT7), a genetic condition characterized by QTc interval prolongation, muscle weakness and paralysis, mood disorders and seizure [87]. Gain-of-function mutations in the KCNJ2 gene (D172N, M301K, E299V and K346T) are instead, linked to QT shortening and increased risk for SCD. Of particular note, a novel p.Phe58Ser missense mutation has been shown to lead to both short QT syndrome type 3 (SQT3) and autism $[88,89]$, with the gain-offunction effect of this mutation consistent with the altered neuronal excitability found in ASD. Distinguishing between mutations that lead to cardiac effects or both cardiac and neuronal effects is likely to provide crucial insights that will inform development of targeted interventions that will treat neurological disorders and prevent off-target cardiac effects.

This connection is also true for NOS1AP (nitric oxide synthase 1 adaptor protein), an adaptor protein that plays a crucial role in both cardiac and neuronal calcium handling mechanisms and ion channel regulation [90]. NOS1AP is important for the activity of the neuronal isoform of NOS (nNOS or NOS1), which in turn modulates different processes but mainly the S-nitrosylation of Cav1.2 channels. Single-nucleotide polymorphisms (SNPs), such as the minor NOS1AP rs16847548, have been associated with decreased expression of NOS1AP resulting in upregulation of $I_{\mathrm{CaL}}$, with increased risk for arrhythmias [91]. NOS1AP has been identified as a modifier gene for LQTS, with SNPs (rs4657139 and rs16847548) associated with QT prolongation in the general population and with an increased risk for SCD in LQT1 patients [92], but it is also a susceptibility locus for schizophrenia (SNPs rs1415263, rs4145621 and rs2661818) [93]. This evidence further reinforces a role for NOS1AP as a key candidate for the crucial mechanistic link that underlies arrhythmogenesis in neuronal disorders.

The most prevalent types of LQTS are caused by mutations in three cardiac channels: KCNQ1, KCNH2 and SCN5A, which have been also associated with epilepsy and sudden unexpected death in epilepsy (SUDEP) [94]. SUDEP is characterized by the absence of any cause of death at post-mortem evaluation, and therefore an arrhythmogenic mechanism is generally suggested. The association between LQTS genes and epilepsy has been complicated by the fact that epileptic seizures can be misinterpreted as syncope due to cardiac arrhythmias in LQTS patients. About one out of five LQT1 patients experiences a seizure phenotype, supporting the idea that KCNQ1 mutations can increase the susceptibility for epileptic seizure [95]. Indeed, a non-synonymous heterozygous missense pathogenic mutation (p.L273F) in exon 6 of the KCNQ1 gene (encoding for the Kv7.1 channel) has been identified in a LQT1 family with recurrent epilepsy [96], further suggesting the neurocardiac effect of this gene.

Mutations and SNPs in KCNH2 have also been linked with epilepsy and SUDEP, and retrospective studies have found that a history of seizures was more common among LQT2 patients compared to the other LQT subtypes [97], and further reinforces an important contribution of KCNH2 defects to epilepsy predisposition. Similarly, a p.W1095X (or p.Trp1095STOP) missense mutation in the SCN5A gene has been identified in subjects showing both Brugada symptoms and epilepsy [98]; and another SCN5A mutation (Pro1090Leu) previously associated with SCD and LQTS, has been found in a SUDEP victim [94].

Growing evidence supports the involvement of ion channels that play a significant role in cardiac function to also play a role in the susceptibility or pathogenesis of psychiatric disorders, but the extension of their contribution may be largely variable. Ion channel mutations can either be the only cause, as occurs in TS, or most commonly, their association with psychiatric disorders is more complex, and can be the result of haplotype effects. SNPs in Ca channel (CACNA1C and CACNB2) genes have been identified as a susceptibility factor for bipolar disorder, schizophrenia and major depression $[99,100]$, suggesting that altered functional expression of voltage-gated Ca channels is an important shared factor in psychiatric disorders. This association is further supported by functional magnetic resonance imaging studies that have correlated the presence of the risk-associated CACNA1C 
SNP (rs1006737) and activation of brain circuitries that are characteristic of patients with mental illness [101].

Mutations in Na channel genes have been extensively linked to epilepsy [102]; however, Okamura's group have reported a link between a novel SCN1A mutation (V1366I) in a Japanese family with different mental illness phenotypes including Asperger syndrome, ASD and panic disorder [103]. Deletion in neuronal specific SCN2A and SCN3A genes have been associated with autism [104] and different forms of epilepsy [105], while loss-offunction mutations in the SCN1A gene are responsible for the comorbidity of psychiatric disorders with epilepsy [106], suggesting that Na channels may be functionally important for emotional and cognitive responses.

$\mathrm{K}$ channels including the KCNQ family play a role in the etiology of psychiatric diseases [107]. For example, KCNQ2 and KCNQ3 genes have been identified as putative risk factors for bipolar disorders [108,109], and in particular, specific KCNQ2 variants (with a shorter C-terminal) are associated with suppressed channel activity, concordant with an effect on neuronal hyperexcitability, characteristic of a manic state [110]. The human ether-à-go-go related (hERG) gene, encoding for the Kv11.1 channel, has also been linked with schizophrenia [111]. Due to the pivotal role for the hERG channel in cardiac repolarization [112], we will discuss its significance in the pathological outcome of brain disorders in subsequent sections below.

Distinct and targeted pharmacological interventions for treatment of psychiatric disorders are known to interact with ion channels, suggesting a potential involvement of off-target cardiac effects of pharmacological treatments designed to treat neurological disorders. Typical antidepressant drugs such as SSRIs have been shown to have an inhibitory effect on Na channel function [113], and more importantly, an elevation in whole-body residual $\mathrm{Na}$ concentration has been observed in patients with depression and particularly those in a manic state, which is an important signature of bipolar disorder and schizophrenia [114]. Similarly, lithium, a well-known pharmacologic, which is used for the treatment of bipolar disorders, has been shown to block cardiac Na channels [115], leading to the unmasking of adverse ECG abnormalities that are characteristic of the Brugada syndrome [116]. Furthermore, Ca channel blockers, such as verapamil and nicardipine, generally used in the treatment of angina, hypertension and supraventricular arrhythmias, have also been shown to display antipsychotic effects [117].

Moreover, antiepileptic drugs that target ion channels are generally prescribed as an effective treatment option for psychiatric disorders (schizophrenia, bipolar and anxiety disorders). For example, a variety of non-selective Na channel blockers initially designed as antiepileptics have also been used as effective therapeutics as mood stabilizers and antidepressants [118], while K channel enhancers or activators act as antipsychotics and/or anticonvulsants $[119,120]$. This broad therapeutic effect of antiepileptic drugs further reinforces the shared pathophysiology that exist between epilepsy and psychiatric disorders and suggests adverse ion channel modulation as a key mechanism linking these pathologies [121].

\section{5. hERG and $I_{K r}$ Channel Modulation as an Important Pathological Link between Neuronal Disorders and Vulnerability to Arrhythmias}

In human heart, hERG1a/1b subunits coassemble to generate $I_{\mathrm{Kr}}$ [112], which is important for normal repolarization [122]. Pathological depression of cardiac $I_{\mathrm{Kr}}$, either due to inherited mutations in hERG or drug-induced, results in a delayed repolarization leading to the prolongation of the $\mathrm{QT}_{\mathrm{C}}$ interval, a disease state that predisposes to fatal arrhythmias such as Torsades des Pointes [123,124], which affects the young and also the old and ultimately the transition to heart failure and sudden cardiac death. hERG channel subunits have an important function in other cell types including neuronal and muscle cells (neuroblastoma cells, neuroendocrine cells and smooth muscle fibers of gastrointestinal tract) [122]. hERG1 is predominantly expressed in the heart, although in the brain, currents through hERG1 channel subunits play an important role in neuronal excitability and firing, while hERG2 and hERG3 are exclusively expressed in the brain [125-127]. 
Similarly, hERG channels expressed in dopamine neurons have been shown to regulate neuronal excitability [126], suggesting that similar, if not identical, hERG channel biophysical properties may exist in both cardiomyocytes and neuronal cells. This notion is reinforced by the demonstration that antipsychotic drugs that display antidopaminergic properties have been shown to interact with hERG channels [128] and this non-selective effect has been suggested to contribute to the therapeutic activity [126] and possible cardiac off-target effects. In most cases of targeted modification of cardiac hERG channel function, major underlying molecular mechanisms include defects in channel gating and trafficking $[112,129,130]$. Therefore, it would be interesting to know whether similar mechanisms underlie neuronal hERG channel functional properties.

Huffacker and others [131] have previously reported the expression of a primate- and brain-specific hERG channel isoform KCNH2-3.1, whose encoding gene is localized in close proximity to the risk-associated SNPs for schizophrenia. This novel isoform has been identified in specific brain regions of individuals affected with schizophrenia and found to harbor schizophrenia susceptibility alleles [131]. In patients with schizophrenia, these risk alleles have not been associated with changes in the functional expression of $\mathrm{KCNH} 2-1 \mathrm{a}$ and $\mathrm{KCNH} 2-1 \mathrm{~b}$, but the ratio between $\mathrm{KCNH} 2-3.1$ and $\mathrm{KCNH} 2-1 \mathrm{a}$ isoform was 2.5-fold higher compared to healthy subjects, suggesting that overexpression of the KCNH2-3.1 isoform could have a prominent role in the pathogenesis of this psychiatric disease [131]. Electrophysiological assays in both HEK cells and rat primary cortical transfected neurons have revealed that currents generated by $\mathrm{KCNH} 2-3.1$ subunits display rapid deactivation kinetics, possibly due to the lack of the $\mathrm{N}$-terminal domain crucial for slow deactivation. This biophysical property may underlie increases in spike frequency and the switch from adapting to non-adapting firing patterns in cortical neurons [131]. Therefore, its enhanced expression is associated with increased neuronal excitability, matching the results observed in brain areas of psychiatric subjects [111,131].

Subjects with the risk genotype associated with higher expression of the KCNH2-3.1 isoform seem to have an increased response to antipsychotic drugs, emphasizing this variant as a possible therapeutic target [132]. The brain specific expression of KCNH2-3.1 could be a highly beneficial target for future treatment options for neurological disorders but without the off-target cardiac effects that are likely to predispose to arrhythmias possibly through adverse modulation of hERG channel function.

\section{Conclusions and Future Directions}

It is becoming increasingly clear that distinct biological, behavioral and psychosocial factors mediate the physiological link between mental illnesses and the increased risk of CVD. Therapeutic strategies are also known to increase the risk for CVD. In fact, antidepressants that target serotonin or norepinephrine reuptake, or antipsychotic drugs blocking dopamine receptors, are the most commonly used therapeutics in clinical interventions [133], and several of these drugs are known to be proarrhythmic, mainly due to their effect of cardiac hERG channels blockade.

Anti-inflammatory treatment strategies in neurological diseases have shown promising results mostly by limiting depressive symptoms [134]. Therefore, a combination of therapeutics including those that target hyperinflammatory cellular signaling pathways, could help to improve outcomes in patients. Moreover, considering the elevated proinflammatory profile found in different psychiatric disorders and the proarrhythmic effect of specific cytokines, therapies that aim at lowering inflammation could both improve psychiatric symptoms and reduce the risk for CVD and arrhythmias.

The majority of studies on the association between arrhythmias and psychiatric disorders describe evidence for ventricular arrhythmias (LQT) but less is known for other forms of arrhythmias. Few trials have attempted to investigate the prevalence of atrial fibrillation in mental disorders, but found that panic disorder and likely anxiety, are associated with increased incidence of atrial fibrillation $[135,136]$. Additional studies assessing the occur- 
rence of other types of arrhythmias in psychiatric disorders could provide further insight into the pathological mechanisms of such diseases.

Further it is known that mental diseases are generally associated with behavioral and/or lifestyle changes including smoking, poor diet, reduced physical activity, alcohol and substance abuse and non-adherence to medications. Therefore, coupling therapeutics with clinical interventions that limit significant changes in individual or multiple combinations of life-style behaviors is likely to reduce the risk of developing cardiovascular diseases that predispose to heart failure.

Finally, the involvement of ion channels in the etiopathology of psychiatric disorders may support the evaluation of alternative targets for the development of pharmacological strategies. The evidence that subjects with a particular neuronal specific hERG isoform (KCNH2-3.1) associated with schizophrenia show a higher responsiveness to antipsychotic drugs and is a relevant example of ion channels as a therapeutic target. Therefore, a comprehensive investigation of the functional interplay between cardiac and neuronal ion channels in the pathogenesis of mental illness and CVD is likely to be rewarded by mechanism-based insights that will help to improve the clinical limitations of existing therapeutic and behavioral interventions in patients.

Author Contributions: J.B. researched concepts and wrote the initial draft of manuscript; K.A.A. edited and finalized manuscript; A.S.A. obtained funding, conceived of, researched concepts, edited, wrote, and finalized the manuscript. All authors have read and agreed to the published version of the manuscript.

Funding: This work was supported by the NIH (R01HL147044 to A.S.A.).

Institutional Review Board Statement: Not applicable.

Informed Consent Statement: Not applicable.

Data Availability Statement: Not applicable.

Disclosures: None.

Conflicts of Interest: The authors declare no conflict of interest.

$\begin{array}{ll}\text { Abbreviations } & \\ \text { ANS } & \text { Autonomic Nervous System } \\ \text { ASD } & \text { Autism Spectrum Disorder } \\ \text { CHD } & \text { Congenital Heart Diseases } \\ \text { CVD } & \text { Cardiovascular Disorders } \\ \text { hERG } & \text { Human Ether-A-Go-Go-Related Gene } \\ \text { HPA axis } & \text { Hypothalamic-Pituitary-Adrenal Axis } \\ \text { HRV } & \text { Heart Rate Variability } \\ I_{\text {Ca,L }} & \text { L-Type Calcium Current } \\ I_{\text {Kr }} & \text { Rapid Delayed Rectifier Potassium Current } \\ I_{\text {to }} & \text { Transient Outward Potassium Current } \\ \text { IL-6 } & \text { Interleukin 6 } \\ \text { IL-1 } \beta & \text { Interleukin 1 } \beta \\ \text { LQTS } & \text { Long QT Syndrome } \\ \text { PNS } & \text { Parasympathetic Nervous System } \\ \text { PTSD } & \text { Post-Traumatic Stress Disorder } \\ \text { QTc } & \text { Corrected QT interval } \\ \text { SCD } & \text { Sudden Cardiac Death } \\ \text { SNP } & \text { Single Nucleotide Polymorphisms } \\ \text { SNS } & \text { Sympathetic Nervous System } \\ \text { SQTS } & \text { Short QT Syndrome } \\ \text { SSRI } & \text { Selective Serotonin Reuptake Inhibitors } \\ \text { TNF- } \alpha & \text { Tumor Necrosis Factor Alpha } \\ \text { TS } & \text { Timothy Syndrome }\end{array}$




\section{References}

1. Sansone, R.A.; Sansone, L.A. Psychiatric disorders: A global look at facts and figures. Psychiatry 2010, 7, 16-19. [PubMed]

2. Correll, C.U.; Solmi, M.; Veronese, N.; Bortolato, B.; Rosson, S.; Santonastaso, P.; Thapa-Chhetri, N.; Fornaro, M.; Gallicchio, D.; Collantoni, E.; et al. Prevalence, incidence and mortality from cardiovascular disease in patients with pooled and specific severe mental illness: A large-scale meta-analysis of 3,211,768 patients and 113,383,368 controls. World Psychiatry 2017, 16, 163-180. [CrossRef] [PubMed]

3. Rosengren, A.; Hawken, S.; Ôunpuu, S.; Sliwa, K.; Zubaid, M.; Almahmeed, W.; Blackett, K.N.; Sitthi-Amorn, C.; Sato, H.; Yusufali, A. Association of psychosocial risk factors with risk of acute myocardial infarction in 11119 cases and 13648 controls from 52 countries (the INTERHEART study): Case-control study. Lancet 2004, 364, 953-962. [CrossRef]

4. Ratajczak, M.Z.; Pedziwiatr, D.; Cymer, M.; Kucia, M.; Kucharska-Mazur, J.; Samochowiec, J. Sterile Inflammation of Brain, due to Activation of Innate Immunity, as a Culprit in Psychiatric Disorders. Front Psychiatry 2018, 9, 60. [CrossRef]

5. Hamer, M.; Molloy, G.J.; Stamatakis, E. Psychological distress as a risk factor for cardiovascular events: Pathophysiological and behavioral mechanisms. J. Am. Coll. Cardiol. 2008, 52, 2156-2162. [CrossRef]

6. Whooley, M. Depressive Symptoms, Health Behaviors, and Risk of Cardiovascular Events in Patients with Coronary Heart Disease. J. Am. Med. Assoc. 2008, 300, 2379-2388. [CrossRef]

7. Correll, C.U.; Detraux, J.; De Lepeleire, J.; De Hert, M. Effects of antipsychotics, antidepressants and mood stabilizers on risk for physical diseases in people with schizophrenia, depression and bipolar disorder. World Psychiatry 2015, 14, 119-136. [CrossRef]

8. Yu, Z.-H.; Jiang, H.-Y.; Shao, L.; Zhou, Y.-Y.; Shi, H.-Y.; Ruan, B. Use of antipsychotics and risk of myocardial infarction: A systematic review and meta-analysis. Br. J. Clin. Pharmacol. 2016, 82, 624-632. [CrossRef]

9. Murray-Thomas, T.; Jones, M.E.; Patel, D.; Brunner, E.; Shatapathy, C.C.; Motsko, S.; Van Staa, T.P. Risk of Mortality (Including Sudden Cardiac Death) and Major Cardiovascular Events in Atypical and Typical Antipsychotic Users: A Study with the General Practice Research Database. Cardiovasc. Psychiatry Neurol. 2013, 2013, 1-15. [CrossRef]

10. Blalock, J.A.; Joiner, T.E. Interaction of Cognitive Avoidance Coping and Stress in Predicting Depres-sion/Anxiety. Cogn. Ther. Res. 2000, 24, 47-65. [CrossRef]

11. Aromaa, A.; Raitasalo, R.; Reunanen, A.; Impivaara, O.; Heliovaara, M.; Knekt, P.; Lehtinet, V.; Joukamaa, M.; Maatela, J. Depression and cardiovascular diseases. Acta Psychiatr. Scand. 1994, 89, 77-82. [CrossRef] [PubMed]

12. Edmondson, D.; Cohen, B.E. Posttraumatic stress disorder and cardiovascular disease. Prog. Cardiovasc. Dis. 2013, 55, 548-556. [CrossRef] [PubMed]

13. Kawachi, I.; Sparrow, D.; Vokonas, P.S.; Weiss, S.T. Symptoms of anxiety and risk of coronary heart disease. The Normative Aging Study. Circulation 1994, 90, 2225-2229. [CrossRef] [PubMed]

14. Westman, J.; Eriksson, S.V.; Gissler, M.; Hällgren, J.; Prieto, M.L.; Bobo, W.V.; Frye, M.A.; Erlinge, D.; Alfredsson, L.; Ösby, U. Increased cardiovascular mortality in people with schizophrenia: A 24-year national register study. Epidemiol. Psychiatr. Sci. 2017, 27, 519-527. [CrossRef] [PubMed]

15. Tyler, C.V.; Schramm, S.C.; Karafa, M.; Tang, A.S.; Jain, A.K. Chronic disease risks in young adults with autism spectrum disorder: Forewarned is forearmed. Am. J. Intellect. Dev. Disabil. 2011, 116, 371-380. [CrossRef]

16. Lane, D.; Carroll, D.; Ring, C.; Beevers, D.G.; Lip, G.Y.H. The prevalence and persistence of depression and anxiety following myocardial infarction. Br. J. Health Psychol. 2002, 7, 11-21. [CrossRef]

17. Lett, H.S.; Blumenthal, J.A.; Babyak, M.A.; Sherwood, A.; Strauman, T.; Robins, C.; Newman, M.F. Depression as a risk factor for coronary artery disease: Evidence, mechanisms, and treatment. Psychosom. Med. 2004, 66, 305-315.

18. Rugulies, R. Depression as a predictor for coronary heart disease. Am. J. Prev. Med. 2002, 23, 51-61. [CrossRef]

19. Moser, D.K.; Dracup, K. Is Anxiety Early after Myocardial Infarction Associated with Subsequent Ischemic and Arrhythmic Events? Psychosom. Med. 1996, 58, 395-401. [CrossRef]

20. Watkins, L.L.; Blumenthal, J.A.; Davidson, J.R.T.; Babyak, M.A.; McCants, C.B.; Sketch, M.H. Phobic Anxiety, Depression, and Risk of Ventricular Arrhythmias in Patients with Coronary Heart Disease. Psychosom. Med. 2006, 68, 651-656. [CrossRef]

21. Rasmussen, K.; Ravnsbaek, J.; Funch-Jensen, P.; Bagger, J.P. Oesophageal spasm in patients with coronary artery spasm. Lancet 1986, 1, 174-176. [CrossRef]

22. Hendriks, M.L.; Allaart, C.P.; Bronzwaer, J.G.; Res, J.J.; De Cock, C.C. Recurrent ventricular fibrillation caused by coronary artery spasm leading to implantable cardioverter defibrillator implantation. Europace 2008, 10, 1456-1457. [CrossRef] [PubMed]

23. Igarashi, Y.; Tamura, Y.; Suzuki, K.; Tanabe, Y.; Yamaguchi, T.; Fujita, T.; Yamazoe, M.; Aizawa, Y.; Shibata, A. Coronary artery spasm is a major cause of sudden cardiac arrest in survivors without underly-ing heart disease. Coron. Artery Dis. 1993, 4, 177-185. [CrossRef] [PubMed]

24. Akosile, W.; Young, R.; Lawford, B.; Voisey, J.; Colquhoun, D. PTSD symptoms associated with myocardial infarction: Practical clinical implications. Australas. Psychiatry 2017, 26, 60-64. [CrossRef]

25. Cohen, B.E.; Marmar, C.; Ren, L.; Bertenthal, D.; Seal, K.H. Association of cardiovascular risk factors with mental health diagnoses in Iraq and Afghani-stan war veterans using VA health care. J. Am. Med. Assoc. 2009, 302, 489-492. [CrossRef]

26. Kubzansky, L.; Koenen, K.C.; Spiro, A.; Vokonas, P.S.; Sparrow, D. Prospective Study of Posttraumatic Stress Disorder Symptoms and Coronary Heart Disease in the Normative Aging Study. Arch. Gen. Psychiatry 2007, 64, 109-116. [CrossRef]

27. Boscarino, J. A Prospective Study of PTSD and Early-Age Heart Disease Mortality Among Vietnam Veterans: Implications for Surveillance and Prevention. Psychosom. Med. 2008, 70, 668-676. [CrossRef] 
28. Edmondson, D.; Kronish, I.M.; Shaffer, J.A.; Falzon, L.; Burg, M.M. Posttraumatic stress disorder and risk for coronary heart disease: A meta-analytic review. Am. Heart J. 2013, 166, 806-814. [CrossRef]

29. Edmondson, D.; Richardson, S.; Falzon, L.; Davidson, K.W.; Mills, M.A.; Neria, Y. Correction: Posttraumatic stress disorder prevalence and risk of recurrence in acute coronary syn-drome patients: A meta-analytic review. PLoS ONE 2012, 7, e38915. [CrossRef]

30. Kronish, I.M.; Edmondson, D.; Goldfinger, J.Z.; Fei, K.; Horowitz, C.R. Posttraumatic Stress Disorder and Adherence to Medications in Survivors of Strokes and Transient Ischemic Attacks. Stroke 2012, 43, 2192-2197. [CrossRef]

31. Roberge, M.-A.; Dupuis, G.; Marchand, A. Post-traumatic stress disorder following myocardial infarction: Prevalence and risk factors. Can. J. Cardiol. 2010, 26, e170-e175. [CrossRef]

32. Fan, Z.; Wu, Y.; Shen, J.; Ji, T.; Zhan, R. Schizophrenia and the risk of cardiovascular diseases: A meta-analysis of thirteen cohort studies. J. Psychiatr. Res. 2013, 47, 1549-1556. [CrossRef] [PubMed]

33. Laursen, T.M.; Wahlbeck, K.; Hällgren, J.; Westman, J.; Ösby, U.; Alinaghizadeh, H.; Gissler, M.; Nordentoft, M. Life Expectancy and Death by Diseases of the Circulatory System in Patients with Bipolar Disorder or Schizophrenia in the Nordic Countries. PLoS ONE 2013, 8, e67133. [CrossRef] [PubMed]

34. Sigmon, E.R.; Kelleman, M.; Susi, A.; Nylund, C.M.; Oster, M.E. Congenital Heart Disease and Autism: A Case-Control Study. Pediatrics 2019, 144, e20184114. [CrossRef]

35. Desnous, B.; Lenoir, M.; Doussau, A.; Marandyuk, B.; Beaulieu-Genest, L.; Poirier, N.; Carmant, L.; Birca, A. Epilepsy and seizures in children with congenital heart disease: A prospective study. Seizure 2019, 64, 50-53. [CrossRef]

36. Ryan, A.K.; Goodship, J.A.; Wilson, D.I.; Philip, N.; Levy, A.; Seidel, H.; Schuffenhauer, S.; Oechsler, H.; Belohradsky, B.; Prieur, M.; et al. Spectrum of clinical features associated with interstitial chromosome 22q11 deletions: A European collaborative study. $J$. Med. Genet. 1997, 34, 798-804. [CrossRef]

37. Wernovsky, G.; Licht, D.J. Neurodevelopmental Outcomes in Children with Congenital Heart Disease-What Can We Impact? Pediatr. Crit. Care Med. 2016, 17 (Suppl. 1), S232-S242. [CrossRef]

38. Mahle, W.T.; Clancy, R.R.; Moss, E.M.; Gerdes, M.; Jobes, D.R.; Wernovsky, G. Neurodevelopmental outcome and lifestyle assessment in school-aged and adolescent chil-dren with hypoplastic left heart syndrome. Pediatrics 2000, 105, 1082-1089. [CrossRef]

39. Haim, T.E.; Wang, W.; Flagg, T.P.; Tones, M.A.; Bahinski, A.; Numann, R.E.; Nichols, C.G.; Nerbonne, J.M. Palmitate attenuates myocardial contractility through augmentation of repolarizing Kv currents. J. Mol. Cell Cardiol. 2010, 48, 395-405. [CrossRef]

40. O'Connell, R.P.; Musa, H.; Gomez, M.S.; Avula, U.M.; Herron, T.J.; Kalifa, J.; Anumonwo, J.M. Free Fatty Acid Effects on the Atrial Myocardium: Membrane Ionic Currents Are Remodeled by the Disruption of T-Tubular Architecture. PLoS ONE 2015, 10, e0133052. [CrossRef]

41. Aromolaran, A.S.; Colecraft, H.M.; Boutjdir, M. High-fat diet-dependent modulation of the delayed rectifier K + current in adult guinea pig atrial myocytes. Biochem. Biophys. Res. Commun. 2016, 474, 554-559. [CrossRef] [PubMed]

42. Martinez-Mateu, L.; Saiz, J.; Aromolaran, A.S. Differential Modulation of $I_{K}$ and $I_{C a, L}$ Channels in High-Fat Diet-Induced Obese Guinea Pig Atria. Front. Physiol. 2019, 10, 1212. [CrossRef] [PubMed]

43. Jana, A.K.; Praharaj, S.K.; Roy, N. Olanzapine-induced Orthostatic Hypotension. Clin. Psychopharmacol. Neurosci. 2015, 13, 113-114. [CrossRef] [PubMed]

44. Roh, S.; Ahn, D.H.; Nam, J.H.; Yang, B.H.; Lee, B.H.; Kim, Y.S. Cardiomyopathy associated with clozapine. Exp. Clin. Psychopharmacol. 2006, 14, 94-98. [CrossRef] [PubMed]

45. Chohan, P.S.; Mittal, R.; Javed, A. Antipsychotic Medication and QT Prolongation. Pak. J. Med. Sci. 2015, 31, 1269-1271. [PubMed]

46. Stock, E.M.; Zeber, J.E.; McNeal, C.J.; Banchs, J.E.; Copeland, L.A. Psychotropic Pharmacotherapy Associated with QT Prolongation Among Veterans with Post-traumatic Stress Disorder. Ann. Pharmacother. 2018, 52, 838-848. [CrossRef]

47. Aronow, W.S.; Shamliyan, T. Effects of antidepressants on QT interval in people with mental disorders. Arch. Med Sci. 2020, 16, 727-741. [CrossRef]

48. Wybraniec, M.T.; Mizia-Stec, K.; Krzych, Ł. Neurocardiogenic injury in subarachnoid hemorrhage: A wide spectrum of catecholamin-mediated brain-heart interactions. Cardiol. J. 2014, 21, 220-228. [CrossRef]

49. Ghadri, J.R.; Wittstein, I.S.; Prasad, A.; Sharkey, S.; Dote, K.; Akashi, Y.J.; Cammann, V.L.; Crea, F.; Galiuto, L.; Desmet, W. International Expert Consensus Document on Takotsubo Syndrome (Part I): Clinical Character-istics, Diagnostic Criteria, and Pathophysiology. Eur. Heart J. 2018, 39, 2032-2046. [CrossRef]

50. De Hert, M.; Detraux, J.; Vancampfort, D. The intriguing relationship between coronary heart disease and mental disorders. Dialog- Clin. Neurosci. 2018, 20, 31-40.

51. Cohen, B.E.; Edmondson, D.; Kronish, I.M. State of the Art Review: Depression, Stress, Anxiety, and Cardiovascular Disease. Am. J. Hypertens. 2015, 28, 1295-1302. [CrossRef] [PubMed]

52. Zorn, J.V.; Schür, R.R.; Boks, M.P.; Kahn, R.S.; Joëls, M.; Vinkers, C.H. Cortisol stress reactivity across psychiatric disorders: A systematic review and meta-analysis. Psychoneuroendocrinology 2017, 77, 25-36. [CrossRef] [PubMed]

53. Taylor, J.L.; Corbett, B.A. A review of rhythm and responsiveness of cortisol in individuals with autism spectrum disorders. Psychoneuroendocrinology 2014, 49, 207-228. [CrossRef] [PubMed]

54. Girod, J.P.; Brotman, D.J. Does altered glucocorticoid homeostasis increase cardiovascular risk? Cardiovasc. Res. 2004, 64, 217-226. [CrossRef] 
55. Etxabe, J.; Vazquez, J.A. Morbidity and mortality in Cushing's disease: An epidemiological approach. Clin. Endocrinol. 1994, 40, 479-484. [CrossRef]

56. Alvares, G.A.; Quintana, D.S.; Hickie, I.B.; Guastella, A.J. Autonomic nervous system dysfunction in psychiatric disorders and the impact of psycho-tropic medications: A systematic review and meta-analysis. J. Psychiatry Neurosci. 2016, 41, 89-104. [CrossRef]

57. Neuhaus, E.; Bernier, R.A.; Beauchaine, T.P. Children with Autism Show Altered Autonomic Adaptation to Novel and Familiar Social Partners. Autism Res. 2016, 9, 579-591. [CrossRef]

58. Carney, R.M.; Freedland, K.E.; Veith, R.C. Depression, the Autonomic Nervous System, and Coronary Heart Disease. Psychosom. Med. 2005, 67, S29-S33. [CrossRef]

59. Park, J.; Marvar, P.J.; Liao, P.; Kankam, M.L.; Norrholm, S.D.; Downey, R.M.; McCullough, S.A.; Le, N.A.; Rothbaum, B.O Baroreflex dysfunction and augmented sympathetic nerve responses during mental stress in veterans with post-traumatic stress disorder. J. Physiol. 2017, 595, 4893-4908. [CrossRef]

60. Thapa, R.; Alvares, G.A.; Zaidi, T.A.; Thomas, E.E.; Hickie, I.B.; Park, S.H.; Guastella, A.J. Reduced heart rate variability in adults with autism spectrum disorder. Autism Res. 2019, 12, 922-930. [CrossRef]

61. Willerson, J.T.; Ridker, P.M. Inflammation as a cardiovascular risk factor. Circulation 2004, 109 (Suppl. 1), II2-II10. [CrossRef] [PubMed]

62. Dowlati, Y.; Herrmann, N.; Swardfager, W.; Liu, H.; Sham, L.; Reim, E.K.; Lanctôt, K.L. A Meta-Analysis of Cytokines in Major Depression. Biol. Psychiatry 2010, 67, 446-457. [CrossRef] [PubMed]

63. Miller, B.J.; Buckley, P.; Seabolt, W.; Mellor, A.; Kirkpatrick, B. Meta-analysis of cytokine alterations in schizophrenia: Clinical status and antipsychotic effects. Biol. Psychiatry 2011, 70, 663-671. [CrossRef] [PubMed]

64. Passos, I.C.; Vasconcelos-Moreno, M.P.; Costa, L.G.; Kunz, M.; Brietzke, E.; Quevedo, J.; Salum, G.A.; Magalhaes, P.V.S.; Kapczinski, F.; Kauer-Sant'Anna, M. Inflammatory markers in post-traumatic stress disorder: A systematic review, meta-analysis, and meta-regression. Lancet Psychiatry 2015, 2, 1002-1012. [CrossRef]

65. Hou, R.; Garner, M.; Holmes, C.; Osmond, C.; Teeling, J.L.; Lau, L.; Baldwin, D.S. Peripheral inflammatory cytokines and immune balance in Generalised Anxiety Disorder: Case-controlled study. Brain Behav. Immun. 2017, 62, 212-218. [CrossRef]

66. Croonenberghs, J.; Bosmans, E.; Deboutte, D.; Kenis, G.; Maes, M. Activation of the Inflammatory Response System in Autism. Neuropsychobiology 2002, 45, 1-6. [CrossRef]

67. Gullestad, L.; Ueland, T.; Vinge, L.E.; Finsen, A.; Yndestad, A.; Aukrust, P. Inflammatory Cytokines in Heart Failure: Mediators and Markers. Cardiology 2012, 122, 23-35. [CrossRef]

68. Lazzerini, P.E.; Capecchi, P.L.; Laghi-Pasini, F. Long QT Syndrome: An Emerging Role for Inflammation and Immunity. Front. Cardiovasc. Med. 2015, 2, 26. [CrossRef]

69. Kouvas, N.; Kontogiannis, C.; Georgiopoulos, G.; Spartalis, M.; Tsilimigras, D.I.; Spartalis, E.; Kapelouzou, A.; Kosmopoulos, M.; Chatzidou, S. The complex crosstalk between inflammatory cytokines and ventricular arrhythmias. Cytokine 2018, 111, 171-177. [CrossRef]

70. Li, Y.H.; Rozanski, G.J. Effects of human recombinant interleukin-1 on electrical properties of guinea pig ventricular cells. Cardiovasc. Res. 1993, 27, 525-530. [CrossRef]

71. Hagiwara, Y.; Miyoshi, S.; Fukuda, K.; Nishiyama, N.; Ikegami, Y.; Tanimoto, K.; Murata, M.; Takahashi, E.; Shimoda, K.; Hirano, T. SHP2-mediated signaling cascade through gp130 is essential for LIF-dependent I CaL, [Ca2+]i transient, and APD increase in cardiomyocytes. J. Mol. Cell Cardiol. 2007, 43, 710-716. [CrossRef] [PubMed]

72. Fernández-Velasco, M.; Ruiz-Hurtado, G.; Hurtado, O.; Moro, M. Ángeles; Delgado, C. TNF- $\alpha$ downregulates transient outward potassium current in rat ventricular myocytes through iNOS overexpression and oxidant species generation. Am. J. Physiol. Circ. Physiol. 2007, 293, H238-H245. [CrossRef] [PubMed]

73. Wang, J.; Wang, H.; Zhang, Y.; Gao, H.; Nattel, S.; Wang, Z. Impairment of HERG K(+) channel function by tumor necrosis factor-alpha: Role of reactive oxy-gen species as a mediator. J. Biol. Chem. 2004, 279, 13289-13292. [CrossRef] [PubMed]

74. Lazzerini, P.E.; Laghi-Pasini, F.; Bertolozzi, I.; Morozzi, G.; Lorenzini, S.; Simpatico, A.; Selvi, E.; Bacarelli, M.R.; Finizola, F.; Vanni, F.; et al. Systemic inflammation as a novel QT-prolonging risk factor in patients with torsades de pointes. Heart 2017, 103, 1821-1829. [CrossRef]

75. Medenwald, D.; Kors, J.A.; Loppnow, H.; Thiery, J.; Kluttig, A.; Nuding, S.; Tiller, D.; Greiser, K.H.; Werdan, K.; Haerting, J. Inflammation and Prolonged QT Time: Results from the Cardiovascular Disease, Living and Ageing in Halle (CARLA) Study. PLoS ONE 2014, 9, e95994. [CrossRef]

76. Empana, J.-P.; Jouven, X.; Canouï-Poitrine, F.; Luc, G.; Tafflet, M.; Haas, B.; Arveiler, D.; Ferrieres, J.; Ruidavets, J.-B.; Montaye, M.; et al. C-Reactive Protein, Interleukin 6, Fibrinogen and Risk of Sudden Death in European Middle-Aged Men: The PRIME Study. Arter. Thromb. Vasc. Biol. 2010, 30, 2047-2052. [CrossRef]

77. Hernesniemi, J.A.; Karhunen, P.J.; Oksala, N.; Kähönen, M.; Levula, M.; Rontu, R.; Ilveskoski, E.; Kajander, O.; Goebeler, S.; Viiri, L.E.; et al. Interleukin 18 gene promoter polymorphism: A link between hypertension and pre-hospital sudden cardiac death: The Helsinki Sudden Death Study. Eur. Heart J. 2009, 30, 2939-2946. [CrossRef]

78. Sgoifo, A.; Carnevali, L.; Grippo, A.J. The socially stressed heart. Insights from studies in rodents. Neurosci. Biobehav. Rev. 2014, 39, 51-60. [CrossRef] 
79. Hodes, G.E.; Pfau, M.L.; Leboeuf, M.; Golden, S.A.; Christoffel, D.J.; Bregman, D.; Rebusi, N.; Heshmati, M.; Aleyasin, H.; Warren, B.L.; et al. Individual differences in the peripheral immune system promote resilience versus susceptibil-ity to social stress. Proc. Natl. Acad. Sci. USA 2014, 111, 16136-16141. [CrossRef]

80. Stewart, A.M.; Roy, S.; Wong, K.; Gaikwad, S.; Chung, K.M.; Kalueff, A.V. Cytokine and endocrine parameters in mouse chronic social defeat: Implications for trans-lational 'cross-domain' modeling of stress-related brain disorders. Behav. Brain Res. 2015, 276, 84-91. [CrossRef]

81. Wood, S.K.; Walker, H.E.; Valentino, R.J.; Bhatnagar, S. Individual Differences in Reactivity to Social Stress Predict Susceptibility and Resilience to a Depressive Phenotype: Role of Corticotropin-Releasing Factor. Endocrinology 2010, 151, 1795-1805. [CrossRef] [PubMed]

82. Hiippala, A.; Tallila, J.; Myllykangas, S.; Koskenvuo, J.W.; Alastalo, T.P. Expanding the phenotype of Timothy syndrome type 2: An adolescent with ventricular fibrilla-tion but normal development. Am. J. Med. Genet. A 2015, 167A, 629-634. [CrossRef]

83. Gillis, J.; Burashnikov, E.; Antzelevitch, C.; Blaser, S.; Gross, G.; Turner, L.; Babul-Hirji, R.; Chitayat, D. Long QT, syndactyly, joint contractures, stroke and novel CACNA1C mutation: Expanding the spectrum of Timothy syndrome. Am. J. Med Genet. Part A 2011, 158A, 182-187. [CrossRef] [PubMed]

84. Kosaki, R.; Ono, H.; Terashima, H.; Kosaki, K. Timothy syndrome-like condition with syndactyly but without prolongation of the QT interval. Am. J. Med Genet. Part A 2018, 176, 1657-1661. [CrossRef] [PubMed]

85. Ramachandran, K.V.; Hennessey, J.A.; Barnett, A.S.; Yin, X.; Stadt, H.A.; Foster, E.; Shah, R.A.; Yazawa, M.; Dolmetsch, R.E.; Kirby, M.L.; et al. Calcium influx through L-type CaV1.2 Ca2+ channels regulates mandibular develop-ment. J. Clin. Investig. 2013, 123, 1638-1646. [CrossRef] [PubMed]

86. Raab-Graham, K.F.; Radeke, C.M.; Vandenberg, C.A. Molecular cloning and expression of a human heart inward rectifier potassium channel. NeuroReport 1994, 5, 2501-2505. [CrossRef] [PubMed]

87. Donaldson, M.R.; Yoon, G.; Fu, Y.-H.; Ptacek, L.J. Andersen-Tawil syndrome: A model of clinical variability, pleiotropy, and genetic heterogeneity. Ann. Med. 2004, 36, 92-97. [CrossRef]

88. Ambrosini, E.; Sicca, F.; Brignone, M.S.; D’Adamo, M.C.; Napolitano, C.; Servettini, I.; Moro, F.; Ruan, Y.; Guglielmi, L.; Pieroni, S.; et al. Genetically induced dysfunctions of Kir2.1 channels: Implications for short QT3 syndrome and autism-epilepsy phenotype. Hum. Mol. Genet. 2014, 23, 4875-4886. [CrossRef]

89. Binda, A.; Rivolta, I.; Villa, C.; Chisci, E.; Beghi, M.; Cornaggia, C.M.; Giovannoni, R.; Combi, R. A Novel KCNJ2 Mutation Identified in an Autistic Proband Affects the Single Channel Properties of Kir2.1. Front. Cell. Neurosci. 2018, 12, 76. [CrossRef]

90. Lu, C.-J.; Hao, G.; Nikiforova, N.; Larsen, H.E.; Liu, K.; Crabtree, M.J.; Li, D.; Herring, N.; Paterson, D. CAPON Modulates Neuronal Calcium Handling and Cardiac Sympathetic Neurotransmission During Dysautonomia in Hypertension. Hypertension 2015, 65, 1288-1297. [CrossRef]

91. Ronchi, C.; Bernardi, J.; Mura, M.; Stefanello, M.; Badone, B.; Rocchetti, M.; Crotti, L.; Brink, P.; Schwartz, P.J.; Gnecchi, M.; et al. NOS1AP polymorphisms reduce NOS1 activity and interact with prolonged repolarization in arrhythmogenesis. Cardiovasc. Res. 2020. [CrossRef]

92. Crotti, L.; Monti, M.C.; Insolia, R.; Peljto, A.; Goosen, A.; Brink, P.A.; Greenberg, D.A.; Schwartz, P.J.; George, A.L., Jr. NOS1AP Is a Genetic Modifier of the Long-QT Syndrome. Circulation 2009, 120, 1657-1663. [CrossRef]

93. Brzustowicz, L.M.; Simone, J.; Mohseni, P.; Hayter, J.E.; Hodgkinson, K.A.; Chow, E.W.C.; Bassett, A.S. Linkage Disequilibrium Mapping of Schizophrenia Susceptibility to the CAPON Region of Chromosome 1q22. Am. J. Hum. Genet. 2004, 74, 1057-1063. [CrossRef]

94. Tu, E.; Bagnall, R.D.; Duflou, J.; Semsarian, C. Post-Mortem Review and Genetic Analysis of Sudden Unexpected Death in Epilepsy (SUDEP) Cases. Brain Pathol. 2010, 21, 201-208. [CrossRef] [PubMed]

95. Glasscock, E. Genomic biomarkers of SUDEP in brain and heart. Epilepsy Behav. 2013, 38, 172-179. [CrossRef] [PubMed]

96. Tiron, C.; Campuzano, O.; Pérez-Serra, A.; Mademont, I.; Coll, M.; Allegue, C.; Iglesias, A.; Partemi, S.; Striano, P.; Oliva, A.; et al. Further evidence of the association between LQT syndrome and epilepsy in a family with KCNQ1 pathogenic variant. Seizure 2015, 25, 65-67. [CrossRef] [PubMed]

97. Johnson, J.N.; Hofman, N.; Haglund, C.M.; Cascino, G.D.; Wilde, A.A.; Ackerman, M.J. Identification of a possible pathogenic link between congenital long QT syndrome and epilepsy. Neurology 2009, 72, 224-231. [CrossRef]

98. Parisi, P.; Oliva, A.; Vidal, M.C.; Partemi, S.; Campuzano, O.; Iglesias, A.; Pisani, D.; Pascali, V.L.; Paolino, M.C.; Villa, M.P.; et al. Coexistence of epilepsy and Brugada syndrome in a family with SCN5A mutation. Epilepsy Res. 2013, 105, 415-418. [CrossRef]

99. Cross-Disorder Group of the Psychiatric Genomics Consortium. Identification of risk loci with shared effects on five ma-jor psychiatric disorders: A genome-wide analysis. Lancet 2013, 381, 1371-1379. [CrossRef]

100. Green, E.K.; Wellcome Trust Case Control Consortium; Grozeva, D.; Jones, I.; Jones, L.; Kirov, G.; Caesar, S.; Gordon-Smith, K.; Fraser, C.; Forty, L.; et al. The bipolar disorder risk allele at CACNA1C also confers risk of recurrent major depression and of schizophrenia. Mol. Psychiatry 2009, 15, 1016-1022. [CrossRef]

101. Bigos, K.L.; Mattay, V.S.; Callicott, J.H.; Straub, R.E.; Vakkalanka, R.; Kolachana, B.; Hyde, T.M.; Lipska, B.K.; Kleinman, J.E.; Weinberger, D.R. Genetic variation in CACNA1C affects brain circuitries related to mental illness. Arch. Gen. Psychiatry 2010, 67, 939-945. [CrossRef] [PubMed]

102. Meisler, M.H.; O’Brien, J.E.; Sharkey, L.M. Sodium channel gene family: Epilepsy mutations, gene interactions and modifier effects. J. Physiol. 2010, 588 Pt 11, 1841-1848. [CrossRef] 
103. Osaka, H.; Ogiwara, I.; Mazaki, E.; Okamura, N.; Yamashita, S.; Iai, M.; Yamada, M.; Kurosawa, K.; Iwamoto, H.; YasuiFurukori, N.; et al. Patients with a sodium channel alpha 1 gene mutation show wide phenotypic variation. Epilepsy Res. 2007, 75, 46-51. [CrossRef] [PubMed]

104. Chen, C.P.; Lin, S.P.; Chern, S.R.; Chen, Y.J.; Tsai, F.J.; Wu, P.C.; Wang, W. Array-CGH detection of a de novo $2.8 \mathrm{Mb}$ deletion in 2q24.2->q24.3 in a girl with autistic features and developmental delay. Eur. J. Med. Genet. 2010, 53, 217-220. [CrossRef] [PubMed]

105. Bartnik, M.; Chun-Hui Tsai, A.; Xia, Z.; Cheung, S.W.; Stankiewicz, P. Disruption of the SCN2A and SCN3A genes in a patient with mental retardation, neurobehavioral and psychiatric abnormalities, and a history of infantile seizures. Clin. Genet. 2011, 80, 191-195. [CrossRef] [PubMed]

106. Scheffer, I.E.; Nabbout, R. SCN1A-related phenotypes: Epilepsy and beyond. Epilepsia 2019, 60 (Suppl. 3), S17-S24. [CrossRef]

107. Imbrici, P.; Camerino, D.C.; Tricarico, D. Major channels involved in neuropsychiatric disorders and therapeutic perspectives. Front. Genet. 2013, 4, 76. [CrossRef]

108. Judy, J.T.; Seifuddin, F.; Pirooznia, M.; Mahon, P.B.; Bipolar Genome Study, C.; Jancic, D.; Goes, F.S.; Schulze, T.; Cichon, S.; Noethen, M.; et al. Converging Evidence for Epistasis between ANK3 and Potassium Channel Gene KCNQ2 in Bipolar Disorder. Front. Genet. 2013, 4, 87. [CrossRef]

109. Kaminsky, Z.; Jones, I.; Verma, R.; Saleh, L.; Trivedi, H.; Guintivano, J.; Akman, R.; Zandi, P.; Lee, R.S.; Potash, J.B. DNA methylation and expression of KCNQ3 in bipolar disorder. Bipolar Disord. 2015, 17, 150-159. [CrossRef]

110. Borsotto, M.; Cavarec, L.; Bouillot, M.; Romey, G.; Macciardi, F.; Delaye, A.; Nasroune, M.; Bastucci, M.; Sambucy, J.L.; Luan, J.J.; et al. PP2A-Bgamma subunit and KCNQ2 K+ channels in bipolar disorder. Pharm. J. 2007, 7, $123-132$.

111. Heide, J.; Mann, S.A.; Vandenberg, J.I. The schizophrenia-associated Kv11.1-3.1 isoform results in reduced current accumulation during repetitive brief depolarizations. PLOS ONE 2012, 7, e45624. [CrossRef] [PubMed]

112. Puckerin, A.; Aromolaran, K.A.; Chang, D.D.; Zukin, R.S.; Colecraft, H.M.; Boutjdir, M.; Aromolaran, A.S. hERG 1a LQT2 C-terminus truncation mutants display hERG 1b-dependent dominant negative mechanisms. Heart Rhythm 2016, 13, 1121-1130. [CrossRef] [PubMed]

113. Aldana, B.I.; Sitges, M. Sertraline inhibits pre-synaptic $\mathrm{Na}(+)$ channel-mediated responses in hippocampus-isolated nerve endings. J. Neurochem. 2012, 121, 197-205. [CrossRef] [PubMed]

114. Shaw, D.M. Mineral metabolism, mania, and melancholia. Br. Med. J. 1966, 2, 262-267. [CrossRef]

115. Yanagita, T.; Maruta, T.; Uezono, Y.; Satoh, S.; Yoshikawa, N.; Nemoto, T.; Kobayashi, H.; Wada, A. Lithium inhibits function of voltage-dependent sodium channels and catecholamine secretion independent of glycogen synthase kinase-3 in adrenal chromaffin cells. Neuropharmacology 2007, 53, 881-889. [CrossRef]

116. Darbar, D.; Yang, T.; Churchwell, K.; Wilde, A.A.; Roden, D.M. Unmasking of brugada syndrome by lithium. Circulation 2005, 112, 1527-1531. [CrossRef]

117. Dubovsky, S.L.; Buzan, R.; Thomas, M.; Kassner, C.; Cullum, C.M. Nicardipine improves the antidepressant action of ECT but does not improve cognition. J. ECT 2001, 17, 3-10. [CrossRef]

118. Large, C.H.; Di Daniel, E.; Li, X.; George, M.S. Neural network dysfunction in bipolar depression: Clues from the efficacy of lamotrigine. Biochem. Soc. Trans. 2009, 37 Pt 5, 1080-1084. [CrossRef]

119. Kristensen, L.V.; Sandager-Nielsen, K.; Hansen, H.H. K(v) 7 (KCNQ) channel openers normalize central 2-deoxyglucose uptake in a mouse model of mania and increase prefrontal cortical and hippocampal serine-9 phosphorylation levels of GSK3beta. $J$. Neurochem. 2012, 121, 373-382. [CrossRef]

120. Wickenden, A.D.; Yu, W.; Zou, A.; Jegla, T.; Wagoner, P.K. Retigabine, a novel anti-convulsant, enhances activation of KCNQ2/Q3 potassium channels. Mol. Pharmacol. 2000, 58, 591-600. [CrossRef]

121. Rogawski, M.A.; Loscher, W. The neurobiology of antiepileptic drugs for the treatment of nonepileptic conditions. Nat. Med. 2004, 10, 685-692. [CrossRef] [PubMed]

122. Schwarz, J.R.; Bauer, C.K. Functions of erg K+ channels in excitable cells. J. Cell Mol. Med. 2004, 8, 22-30. [CrossRef] [PubMed]

123. Khan, I.A. Clinical and therapeutic aspects of congenital and acquired long QT syndrome. Am. J. Med. 2002, 112, 58-66. [CrossRef]

124. El-Sherif, N.; Turitto, G. Torsade de pointes. Curr. Opin. Cardiol. 2003, 18, 6-13. [CrossRef] [PubMed]

125. Guasti, L.; Cilia, E.; Crociani, O.; Hofmann, G.; Polvani, S.; Becchetti, A.; Wanke, E.; Tempia, F.; Arcangeli, A. Expression pattern of the ether-a-go-go-related (ERG) family proteins in the adult mouse central nervous system: Evidence for coassembly of different subunits. J. Comp. Neurol. 2005, 491, 157-174. [CrossRef] [PubMed]

126. Ji, H.; Tucker, K.R.; Putzier, I.; Huertas, M.A.; Horn, J.P.; Canavier, C.C.; Levitan, E.S.; Shepard, P.D. Functional characterization of ether-a-go-go-related gene potassium channels in midbrain dopamine neurons-Implications for a role in depolarization block. Eur. J. Neurosci. 2012, 36, 2906-2916. [CrossRef]

127. Chiesa, N.; Rosati, B.; Arcangeli, A.; Olivotto, M.; Wanke, E. A novel role for HERG K+ channels: Spike-frequency adaptation. J. Physiol. 1997, 501 Pt 2, 313-318. [CrossRef]

128. Kongsamut, S.; Kang, J.; Chen, X.L.; Roehr, J.; Rampe, D. A comparison of the receptor binding and HERG channel affinities for a series of antipsychotic drugs. Eur. J. Pharmacol. 2002, 450, 37-41. [CrossRef]

129. Sale, H.; Wang, J.; O’Hara, T.J.; Tester, D.J.; Phartiyal, P.; He, J.Q.; Rudy, Y.; Ackerman, M.J.; Robertson, G.A. Physiological properties of hERG 1a/1b heteromeric currents and a hERG 1b-specific mutation associated with Long-QT syndrome. Circ. Res. 2008, 103, e81-e95. [CrossRef] 
130. Aromolaran, A.S.; Srivastava, U.; Ali, A.; Chahine, M.; Lazaro, D.; El-Sherif, N.; Capecchi, P.L.; Laghi-Pasini, F.; Lazzerini, P.E.; Boutjdir, M. Interleukin-6 inhibition of hERG underlies risk for acquired long QT in cardiac and systemic inflammation. PLoS ONE 2018, 13, e0208321. [CrossRef]

131. Huffaker, S.J.; Chen, J.; Nicodemus, K.K.; Sambataro, F.; Yang, F.; Mattay, V.; Lipska, B.K.; Hyde, T.M.; Song, J.; Rujescu, D.; et al. A primate-specific, brain isoform of $\mathrm{KCNH} 2$ affects cortical physiology, cognition, neuronal repolarization and risk of schizophrenia. Nat. Med. 2009, 15, 509-518. [CrossRef] [PubMed]

132. Apud, J.A.; Zhang, F.; Decot, H.; Bigos, K.L.; Weinberger, D.R. Genetic variation in KCNH2 associated with expression in the brain of a unique hERG isoform modulates treatment response in patients with schizophrenia. Am. J. Psychiatry 2012, 169, 725-734. [CrossRef] [PubMed]

133. Uher, R.; Tansey, K.E.; Dew, T.; Maier, W.; Mors, O.; Hauser, J.; Dernovsek, M.Z.; Henigsberg, N.; Souery, D.; Farmer, A.; et al. An inflammatory biomarker as a differential predictor of outcome of depression treatment with escitalopram and nortriptyline. Am. J. Psychiatry 2014, 171, 1278-1286. [CrossRef] [PubMed]

134. Raison, C.L.; Rutherford, R.E.; Woolwine, B.J.; Shuo, C.; Schettler, P.; Drake, D.F.; Haroon, E.; Miller, A.H. A randomized controlled trial of the tumor necrosis factor antagonist infliximab for treatment-resistant depression: The role of baseline inflammatory biomarkers. JAMA Psychiatry 2013, 70, 31-41. [CrossRef]

135. Cheng, Y.F.; Leu, H.B.; Su, C.C.; Huang, C.C.; Chiang, C.H.; Huang, P.H.; Chung, C.M.; Lin, S.J.; Chen, J.W.; Chan, W.L. Association between panic disorder and risk of atrial fibrillation: A nationwide study. Psychosom. Med. 2013, 75, 30-35. [CrossRef]

136. Eaker, E.D.; Sullivan, L.M.; Kelly-Hayes, M.; D'Agostino, R.B., Sr.; Benjamin, E.J. Tension and anxiety and the prediction of the 10-year incidence of coronary heart disease, atrial fibrillation, and total mortality: The Framingham Offspring Study. Psychosom. Med. 2005, 67, 692-696. [CrossRef] 